\title{
Ancient Song Re-employed: The Use of Regilaul in the Music of Veljo Tormis
}

\author{
Mark LAWRENCE \\ 88 Belmont Road, BS6 5AU St Andrews, Bristol, United Kingdom \\ E-mail: markrlawrence@virginmedia.com
}

(Received: April 2015; accepted: June 2015)

\begin{abstract}
The music of Veljo Tormis (b. 1930) became well-established in Estonia during the 1960s yet remained little known in the West until the fall of Communism. By incorporating traditional Estonian folk song, regilaul, into his works, Tormis's name became closely associated for Estonians with upholding a sense of national identity against the Soviet regime. It is his vast output of some 500 choral songs for which he is most immediately recognised; indeed, once regilaul had come to dominate the 'Tormis style', he dedicated himself almost exclusively to choral composition. This paper examines regilaul, its impact on Tormis during his formative years, and its integration into his mature compositional style, leading him to claim that he had 'found his voice' as a composer.
\end{abstract}

Keywords: Veljo Tormis, Estonian folk song regilaul

It is not I who make use offolk music; it is folk music that makes use of me. ${ }^{1}$

In this paper I will look at the way in which Veljo Tormis (b. 1930) employs ancient Estonian folk song, regilaul, in his choral compositions. Although not the first composer to use the song, Tormis's relationship with regilaul was to become inseparable from his mature compositional style, and indeed, a fundamental part of his identity as a composer. It is through his regilaul-based works that Tormis's distinct voice as a choral composer is most recognisable.

1. Veljo Tormis, postscript to vocal score, Eesti Ballaadid [Estonian ballads], I (Leningrad: Sovietsky Kompositor, 1987). This paper's title respectfully echoes that of the authoritative biography of Tormis by Mimi Daitz, Ancient Song Rediscovered: The Life and Music of Veljo Tormis (New York: Pendragon, 2004). 
Firstly, a brief examination of the song itself. Meaning literally 'verse-song', the term regilaul applies to alliterative songs predating the Christianisation of Estonia in the $13^{\text {th }}$ century. They belong to a tradition shared by the former communities of Livs, Vots, Izhorians and Karelians around the Baltic coast, as well as Finland. ${ }^{2}$ The term regilaul had been applied to the text of Estonian alliterative or 'runic' verse by collectors such as Jakob Hurt as far back as the nineteenth century, but Tormis claims that he and folk song scholar Ülo Tedre, in their themed anthology Uus Regilaulik [The new regilaul] were the first to apply the term to both words and their melodies; the two are inseparable in traditional regilaul practice. ${ }^{3}$ Characteristics of regilaul are short melodic lines with a small vocal range, often of no more than a fourth, and a rhythmic structure based on the four-footed trochee. The first syllable of each foot is stressed, and the final syllable of the line lengthened. ${ }^{4}$ Melodies are repeated many times, while the words evolve verse by verse through alliteration and word play, often with an improvisatory element. A typical style of regilaul singing uses two voices who sing alternate lines. These share the last note of one line and the first of the next, thus forming a continuous 'chain' of sound (Example 1).

EXAMPLE 1 Regilaul from Jõelähtme parish, as used in Veljo Tormis, 'Laevamäng'
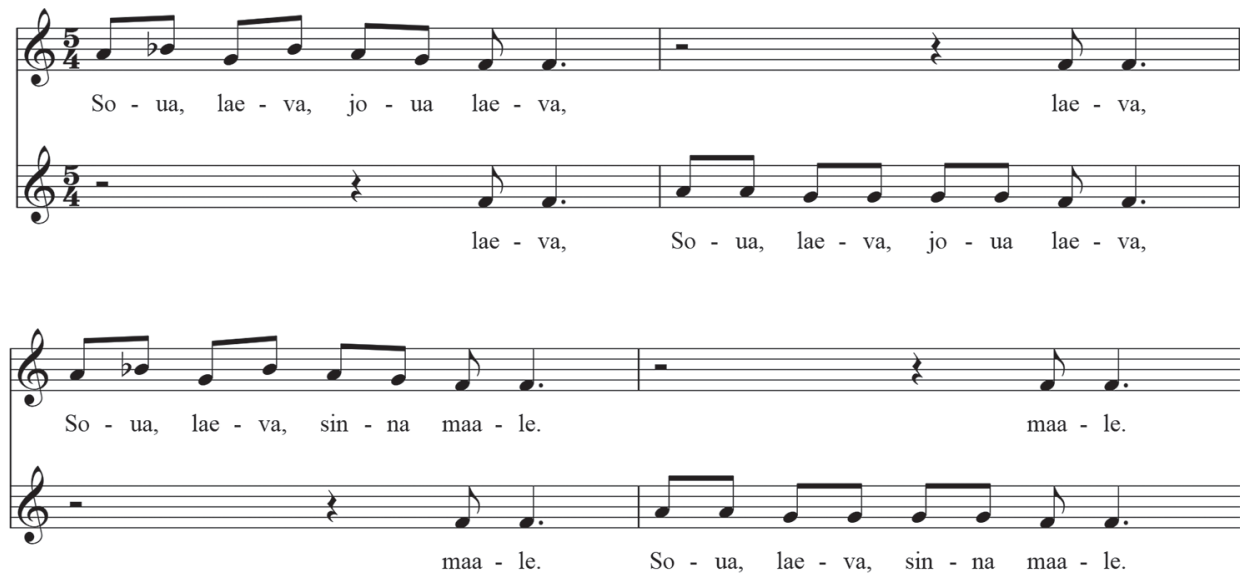

2. The Finnish equivalent is runolaul. Tormis claims that the term regilaul 'cannot be translated exactly into English.' (Author discussion with Tormis, Cheltenham International Music Festival, Cheltenham, UK, 11 July 2008).

3. Ülo Tedre - Veljo Tormis, Uus Regilaulik [The new regilaul] (Tallinn: Muusikaprojekt, 1975, rev. 1997).

4. Mari Sarv, 'Language and Poetic Metre in Regilaul', www.tormis.ee 
Lippus stresses that regilaul songs, being ancient monophonic melodies, are fundamentally linear in character: that is, they exist without an implied underlying chord structure. ${ }^{5}$ They therefore differ distinctly from the ballads, lullabies and other end-rhymed 'folk' songs from Western Europe which were introduced via the Swedish and Baltic German overlords in the $18^{\text {th }}$ and $19^{\text {th }}$ centuries. Regilaul songs, transmitted orally, formed an essential part of everyday working life well into the twentieth century in many of the remoter parts of Estonia, such as the island of Kihnu and semi-autonomous region of Setumaa (in the southeast of the country). Regilaul themes include farming: herding, sowing, reaping, and harvesting; children's games and lullabies; courtship songs and wedding ceremonies in which the customs of 'mocking the groom' and 'lamenting the bride' are seen; bear wakes (animistic practices where the 'spirit' of the bear is celebrated following the hunt); songs for singing aboard ship; laments and spells. Particularly important are songs for large-scale festivals in the calendar year, such as Jaanipäev [St John's Day or Midsummer Eve]. This is the most important annual festival, even today, in Estonia and other Nordic countries, and involves extensive dancing, communal singing and the lighting of huge bonfires. ${ }^{6}$

The earliest field recordings of regilaul date back to 1912, but the bulk of their collection was made by Herbert and Erna Tampere between 1956 and 1965. The Tamperes collated and edited the material into five volumes, Eesti Rahvalaule Viisidega [Estonian folk songs with notations] and it was these collections, held at the Estonian Literary Museum in Tartu, on which Tormis was to draw extensively in his work. ${ }^{7}$ Example 2 shows an extract of regilaul transcribed by the Tamperes, from these field recordings. Herbert Tampere (1909-1975) played a further role in bringing regilaul to public awareness through a popular radio series on Estonian folk music which he presented in the 1960s, and in his latter years he organised performances of regilaul at the Music and Theatre Museum in Tallinn (Example 2).

Tormis believes that he first encountered regilaul as a young organist alongside his father, a köster at the Lutheran church in his home village of Kullamäe, through the organ works of Edgar Arro (1911-1978). These works were staple repertoire for Estonian organists in the 1940s. ${ }^{8}$ In works such as the six volumes of Eesti Rahvaviisid [Estonian folk melodies], Arro leaves the folk melodies intact while

5. Urve Lippus, Linear Musical Thinking: A Theory of Musical Thinking and the Runic Song Tradition of Baltic-Finnish Peoples (Helsinki: University of Helsinki, 1995) (= Studia Musicologica Universitatis Helsinkiensis 7), 10-11. Lippus does qualify this point by saying that the harmonic dimension is not entirely missing; it exists 'in the acoustic nature of musical notes'. (Author discussion with Lippus, Estonian Academy of Music and Drama, February 2013.) 1996).

6. Veljo Tormis, note in score, Eesti Kalendrilaulud [Estonian calendar songs] (Helsinki: Edition Fazer,

7. Eesti Rahvamuusika Antoloogia [Anthology of Estonian folk music], eds Herbert and Erna Tampere. Field recordings, re-mastered as 3-CD set with booklet containing transcriptions of regilaul by the Tamperes, and CD sleeve note by Janika Oras (Tartu: Eesti Kirjandusmuuseum, 2003). ISSN 1736-0528, EMKCD 005.

8. Author discussion with Tormis, Cheltenham. Köster is a Swedish term for the role akin to that of Sacristan: organist, choir master and organiser of church concerts. 
ExAmple 2 Regilaul transcribed by Herbert and Erna Tampere from their own field recordings

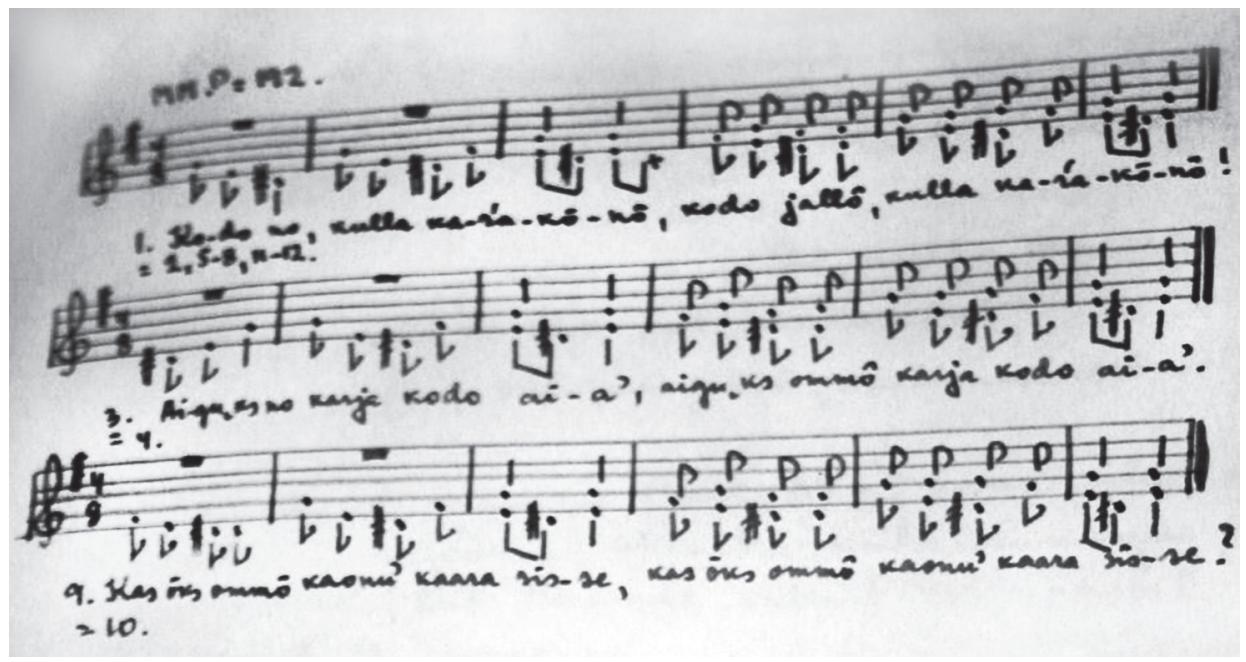

weaving countermelodies, canonic and contrapuntal material around them, often with inventive chromatic harmonisations undoubtedly indebted to J. S. Bach's chorale preludes. Tormis was to turn his attention to regilaul from a composer's perspective when studying at the Moscow Conservatory in the early 1950s, greatly encouraged by his teacher of composition, Vissarion Shebalin (1902-1963). Braving the repressive climate of the Zhdanov era to introduce then-prohibited composers such as Debussy to his students, Shebalin recommended Tormis take a 'non-romantic' approach to folk material. Rather than use it as a basis for thematic development, as had been the traditional $19^{\text {th }}$-century approach, he advocated that melodies be preserved 'whole', intact, within a composition, with development and variety provided by the accompanying material and texture. This was to remain a guiding principle throughout Tormis's mature choral works, and Tormis continues to acknowledge Shebalin's influence with warm respect. ${ }^{9}$

In 1958 Tormis read an article by Ingrid Rüütel which discussed the traditional wedding ceremonies on Kihnu, a small island off the west coast of Estonia. ${ }^{10} \mathrm{At}$ this time, these traditions survived with all their associated rituals, songs and dances. Tormis was inspired to make a week-long visit to the island with a group

9. Author discussion with Tormis, Cheltenham.

10. Ingrid Rüütel, 'Wedding Songs and Ceremonies of the Kihnu Island in Estonia', The World of Music 44/3 (2002), 131-151. Rüütel points out in this article that the rhythms of the Kihnu songs derive from everyday activity. In this case, this would probably be 'the movement of an object such as a cradle or swing, or stamping feet'. This fact underlines the functional nature of the original songs. Kihnu Island, like much of the coast and islands, was out of bounds to Estonians in Soviet times, thus preserving customs and traditions for longer than on the mainland. (Author discussion with Tormis, Estonian Academy of Music and Drama, Tallinn, February 2010). 
of students, an experience which was profoundly moving for him. He realised at first hand how fragile this surviving tradition was, and how soon it could be lost. The visit impelled him to compose his first choral work to incorporate regilaul: Kihnu Pulmalaulud [Kihnu wedding songs] (1959). ${ }^{11}$ This work casts an interesting light on the development of Tormis's style, both melodically and in its accompanying material. While the work is based on authentic regilaul melodies, Tormis at this stage treats them with some freedom: varying and elaborating them. In the first song, for example, 'Ei või ónneta elada!' [I cannot live without happiness!] the four phrases forming the first verse are authentic regilaul (Example 3). In the

EXAMPLE 3 Veljo Tormis, 'Ei või ônneta elada!,' bars 9-14

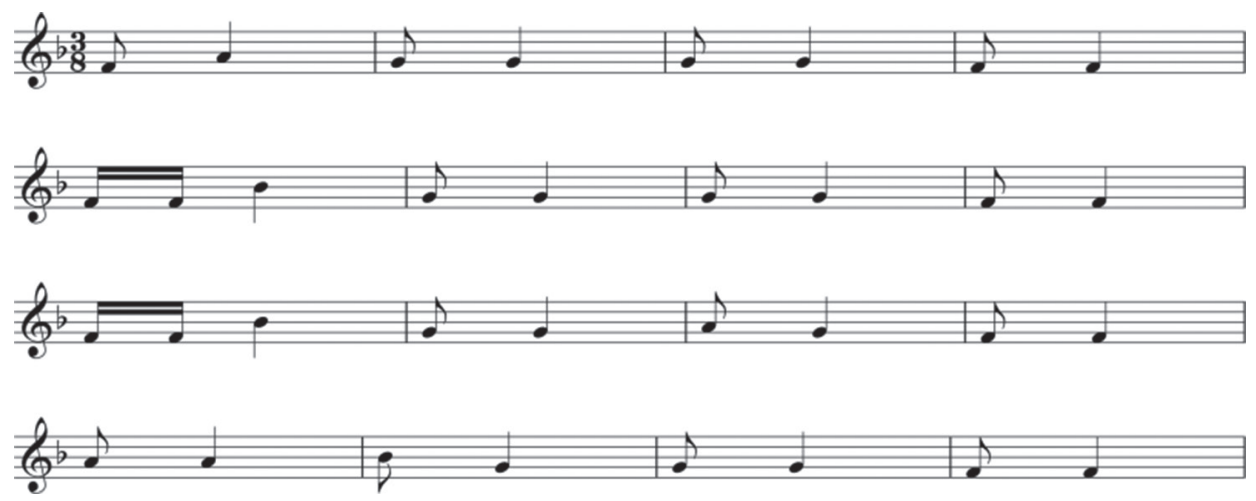

second 'verse', however, given to the solo soprano (beginning 'Olgu kuub küll kumma legi', from bars 49 to 60), Tormis varies the melodic line to create what could be called a musically conventional sense of development and climax, rising a fourth from $\mathrm{D}$ up to a top $\mathrm{G}$ at bar 57. In later works, Tormis would on occasions make a stepwise change to a melody, but would rarely make significant intervallic changes. ${ }^{12}$ Harmonically, with its simple four-part diatonic chordal accompaniment over a pedal bass, Tormis's language in Kihnu Pulmalaulud, while idiosyncratic and already recognisable as an individual voice, echoes the early $20^{\text {th }}$-century idiom of the founders of the 'Estonian School': choral composers such as Mart Saar (1882-1963) and Cyrillus Kreek (1889-1962), both of whom, incidentally, had shared Tormis's fascination with folk music. ${ }^{13}$ In Kihnu Pulmalaulud, the most recognisable hallmarks of Tormis's later harmonic language, parallelism and the extensive use of dissonance (2nds, 7ths and 9ths, and by extension, 11ths and 13ths) are as yet absent.

11. Kihnu Pulmalaulud (Bremen: Eres Edition, 1996).

12. Author discussion with Urve Lippus by e-mail, 19 January 2015.

13. Author discussion with Evi Arujärv, EMIC (Estonian Music Information Centre), February 2011. 
In terms of choral accompaniment, however, this work anticipates some important aspects of Tormis's mature choral style. In the second verse of the first song, for example, the melody moves phrase by phrase from bass to alto to solo soprano part, where it is transposed and extended, to a wordless melisma for the whole choir. This procedure is to become a Tormis hallmark: a subsidiary idea derived from the original material is extended and harmonically enriched, at first entering almost unnoticed in the accompaniment, and then gradually taking on a dominant role. In 'Ei või onnneta elada!' the wordless melisma seems to offer a commentary from the choir on the emotions of the song; wordless, since the emotions are literally 'beyond words'. This procedure is to be seen again, more fully developed, in 'Laevamäng' [Boat game], discussed later in this paper. ${ }^{14}$

In the mid-1960s, now in his 30s, Tormis found what he considers his 'mature voice': the full integration of regilaul into his choral idiom. ${ }^{15}$ The cycle Eesti Kalendrilaulud [Estonian calendar songs] consists of five sets of songs based on festivals in the traditional Estonian farming year. ${ }^{16}$ 'Jaanilaul' [St John's song] (1967) is the final song of the cycle, and marks the most important festival in the traditional Estonian calendar, Jaanipäev [St John's Day]. (The regilaul melody is shown in Example 4.) Tormis now preserves the short regilaul melody intact, yet

EXAMPLE 4 Original regilaul melody, 'Jaanilaul'

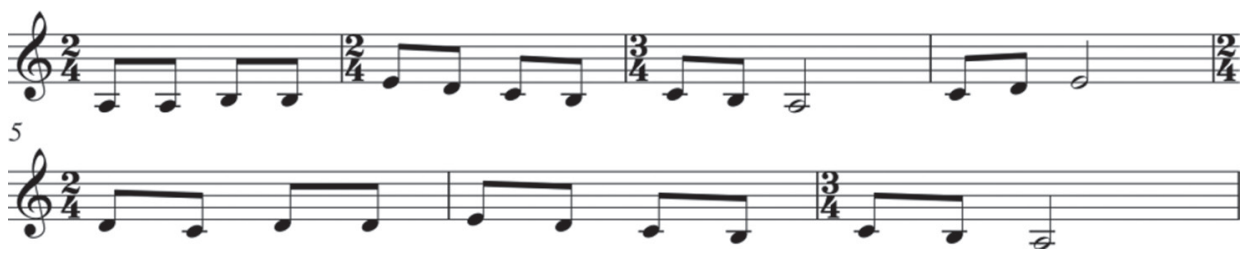

succeeds in creating a vast emotional spectrum in the course of this choral song of some five minutes' duration. A sense of inevitable onward movement is achieved by a crescendo through almost the whole song, mirroring the progression of mood from hushed reverence (awe in anticipation of the Saint's appearance) at the opening, to an ecstatic coda (his arrival). But also, with each new entry, the grouping of the voices and choral colouring changes. Sometimes the melody is doubled at the octave above or below; sometimes it is enhanced by simple imitation, sometimes harmonised in parallel triads or chords of major 7ths or 9ths to create a gradual

14. 'Laevamäng’ [Boat song] from Kolm Eesti Mängulaulud [Three Estonian game songs] (Espoo: Edition Fazer, 1991).

15. Tormis considers Eesti Kalendrilaulud to be a turning point in his musical development. (Author discussion with Tormis, Cheltenham, 2008).

16. 'Jaanilaulud' [St John's songs] from Eesti Kalendrilaulud [Estonian calendar songs] in 6 sets (19691972) (Helsinki: Edition Fazer, 1996). Eesti Kalendrilaulud won the Prize of Soviet Estonia in 1970 and was performed in Arezzo, Italy, the following year. See Daitz, Ancient Song, 181. 
thickening of the texture. Not until the final entry (at bar 104) is the choir heard as a whole, now divisi into nine (and later, twelve) parts. For the first time, the regilaul melody is heard harmonised (in parallel 11th chords), the upper voices doubled an octave lower by tenors and basses. By marking dynamics down to a sudden piano, Tormis creates the effect of a great force held in check, like an organ played with the swell box closed. ${ }^{17}$ Tormis has on many occasions denied the influence of the organ on his choral writing, yet he recollects the thrill he felt as a child 'when pulling out the stops to increase the registration'. ${ }^{18}$ It is hard not to imagine that his technique of cumulative choral scoring owes at least an unconscious debt to sonorities absorbed during early years spent at the organ. The coda of 'Jaanilaul' provides a further example of this. After the climax at bar 133, the $\mathrm{D} 11$ th chord is held by the lower voices, while the upper voices repeat it an octave lower, now to a wordless 'aa' sound, $p p p$, finally surrendering to the most subtle of echoes, a hummed chord, $p p p p$, in the men's voices, an octave lower still, creates a stunningly resonant effect (Example 5).

The short song, 'Laevamäng' [Boat song] from Kolm Eesti Mängulaulud [Three Estonian game songs] (1972) describes a ship setting sail, apparently to a childlike 'land of dreams', to find birds and animals 'made of gold'. But the skipper is warned of rocky reefs; the wind changes direction and the ship is wrecked. No longer will the sweep-net reveal treasures, but instead, the dead bodies of sailors. The regilaul melody comprises two eight-note, near-identical melodic phrases, differing only by three pitches, all contained within the interval of a perfect fourth (seen in Example 1). Seen in 'conventional' tonal terms, the centre would be F, which would imply an underlying $\mathrm{F}$ major or D minor harmonisation. However, Tormis accompanies the melody with an A major triad. This bitonality creates a sense of unease, and hints, subtly at first, of the disaster to come. The unease is heightened by the restless oscillations in the bass line, in irregular metre, between the chords of A and $\mathrm{G}$ major. This song again exploits cumulative scoring technique: the initial triad in the choral accompaniment is doubled in octaves, firstly in the bass, then in the tenor, then the soprano register. The regilaul melody is repeated a total of sixteen times, unchanged, without a break, with only the slightest of melodic additions. The onward direction is provided solely by the incremental crescendo in the chording, from $p p p$ to $f f$, with a corresponding halving of note values in the accompanying chords. This song recalls the techniques of modernist composers of this period, reminding of that 'unbroken state of transformation' in such contemporary choral works as Ligeti's Atmosphères (1960). ${ }^{19}$

17. Tormis described this effect as that of 'a wild animal in a cage'. (Author discussion with Tormis, Cheltenham, 2008).

18. Daitz, Ancient Song, 100.

19. Richard Toop, György Ligeti (London: Phaidon, 1999), 76. 
ExAmple 5 Final bars of 'Jaanilaul' showing Tormis's use of 'choral orchestration'
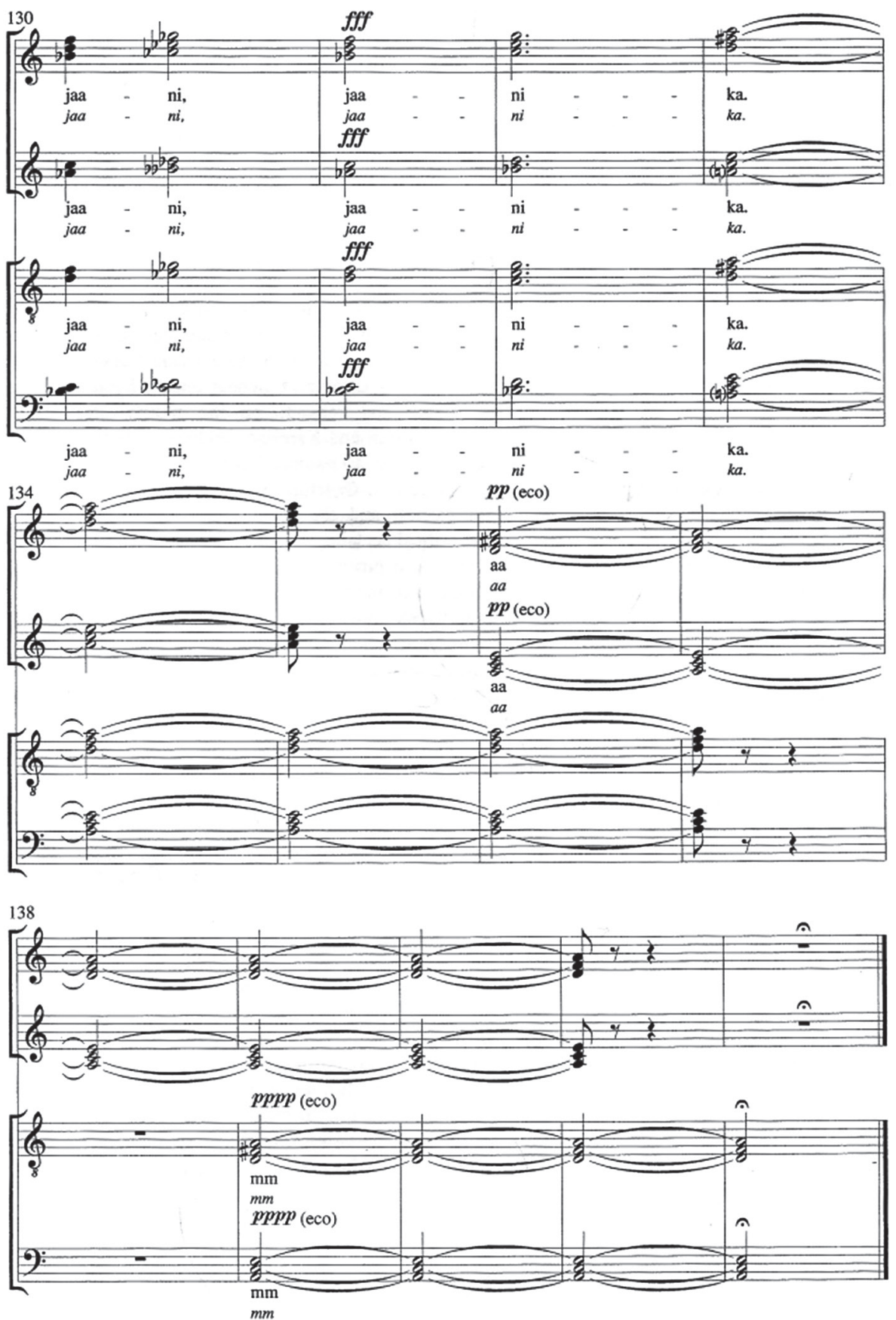
It was observed in Kihnu Pulmalaulud that subsidiary material, derived from the regilaul melody, is often used by Tormis to form the choral accompaniment and that this material embodies the emotions of the song. In 'Laevamäng', the

\section{Example 6 Veljo Tormis, 'Laevamäng'}

a) melody

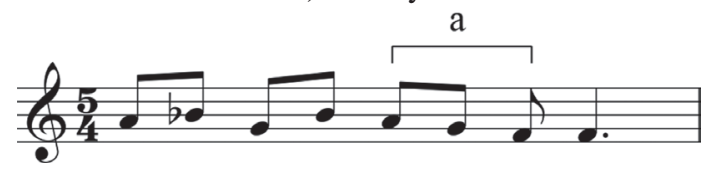

b) subsidiary material

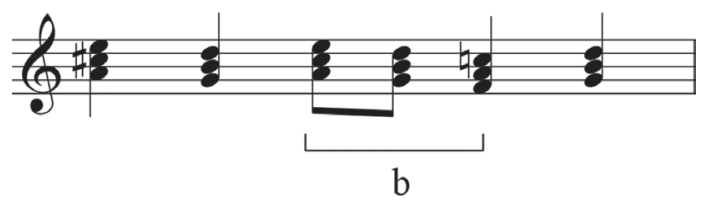

idea is developed further. The subsidiary idea consists of an element of the regilaul melody, filled out with parallel triads (Example 6). The wordless, 'subsidiary' choral material has taken centre stage by the end of verse 16, now fortissimo, and presents a very much more threatening face. If the danger was subtly present at the beginning of the song, only now does it reach its full force. The dramatic climax consists of four superimposed triads, widely spaced, using all 12 notes of the chromatic scale. Fragments of the now-dismembered regilaul melody, to the words 'Arju sepp, minu armas venda' [Make me a net of steel whereby I shall draw men from the sea], are passed between the sopranos and altos. Through the use of bitonality, the melody and harmony are now unrelated, creating the impression that, with the loss of the ship, there has also been a loss of a stable tonality (Example 7).

'Laevamäng' is a mature Tormis work which could, on first hearing, attract the popular categorisation for its composer of 'minimalist'. Fragments of motif-like material are repeated relentlessly against a slowly evolving harmony. The starting material is stripped down to its essence, and the piece has no non-essential or decorative elements. But Tormis's work takes its character from the original regilaul words and melody. The setting serves the authentic text; the repetition itself is that of the regilaul song tradition, just as traditional African drumming or Balinese gamelan are, by their nature, based on repeating and slowly evolving pattern. 'Laevamäng' could only be termed 'minimalist' if the term can be applied to the style of the regilaul tradition itself, which is clearly impossible. Minimalism was a specific movement to which Tormis has never claimed any adherence. Lippus has, in addition, pointed out that it would have been almost impossible for Tormis 
Example 7 Veljo Tormis, 'Laevamäng', bars 32-38
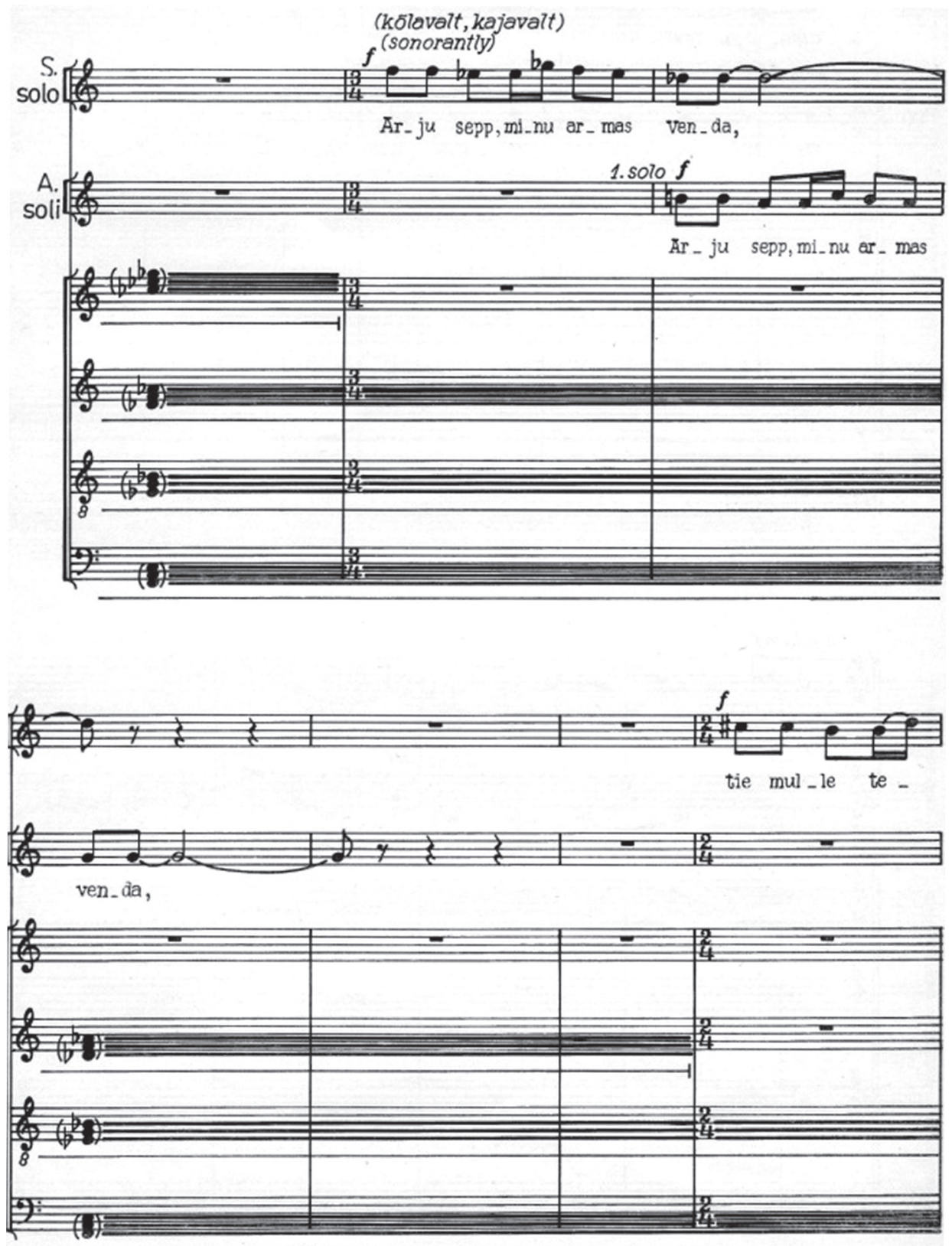
to have gained access to recordings or scores of the American minimalist works (such as those of Steve Reich) under the Soviet regime of the 1960s and 1970s. ${ }^{20}$ The fact that some of his works superficially bear some minimalist traits is a matter of accident rather than design.

The 1970s produced two landmarks in Tormis's oeuvre: Raua Needmine [Curse upon iron] (1972), for choir, shaman drum and soloists and Eesti Ballaadid [Estonian ballads] (1980). Raua Needmine is an uncompromising anti-war work, written at the height of East-West tensions. It is the best known and most performed of Tormis's larger works outside Estonia, and the one work which was performed outside the Soviet Bloc in communist times. In this work, regilaul melodies and text from the Kalevala are interposed with modern Estonian text, inspiring Tormis's most modernist choral idiom. Eesti Ballaadid is a ballet-cantata for large forces and, at ninety minutes, is Tormis's longest and largest-scale work. As yet rarely performed outside Estonia, it is based on a judicious selection by the composer's wife, Lea Tormis, of ancient songs and texts derived from the Finnish epic, Kalevala.

In 2000, Tormis announced his last composition, 'Lauliku Lopusõnad' [The singer's closing words], a setting for mixed chorus of the final lines from the $\mathrm{Ka}$ levala, spoken by the shaman figure, Väinämoinen, in old age. The passage ends with the words 'Now my song remains completed', implying that it is time to surrender their speaker's power to a younger singer. Deeply ingrained traditions from the time of the Kalevala (and its Estonian equivalent, Kalevipoeg) perhaps survive in the Estonian consciousness up to this day: in the text, Väinämoinen departs to make way for the new, and for a renewal of life forces. ${ }^{21}$ Tormis's last work thus pays tribute to the power of the song that was to become an intrinsic part of his voice as a composer.

20. Author discussion with Lippus, Estonian Academy of Music and Drama, 13 February 2013.

21. Daitz, Ancient Song, 151. 